\title{
Exploration of Local Wisdom-Based Physics Learning Resources in the COKSACAR Case Study
}

\author{
Ulfi Meiyana ${ }^{1}$, Rizki Ardiawan ${ }^{2}$, Fiqoh Khoeriyah ${ }^{3}$, Ahmad Khoiri $^{4, *}$, Sri Jumini $^{5}$, Firdaus ${ }^{6}$ \\ Department of Physics Education, Universitas Sains Al-Qur'an, Central Java, Indonesia ${ }^{1,2,4,5,6}$, \\ Department of Accounting, Universitas Sains Al-Qur'an, Central Java, Indonesia ${ }^{3}$ \\ akhoiri@unsiq.ac.id ${ }^{4}$ \\ ${ }^{*}$ Corresponding author
}

Keywords:

Entrepreneur; Local Wisdom; Physics Learning Resource; Viscosity

\begin{abstract}
Research objectives were to (1) Know the exploration of learning resources based on local wisdom; (2) To find out that local wisdom can be used as a learning resource in Viscosity material; (3) How to grow the entrepreneurial spirit with learning resources based on local wisdom. Qualitative descriptive research method with inductive and deductive analysis techniques. Data collection methods used documentation and participatory observation. The results showed that: (1) The form of exploration of learning resources based on local wisdom in the Wonosobo area was carried out with processed food products, namely COKSACAR. COKSACAR is a processed product of Carica fruit combined with chocolate. (2) The process of making COKSACAR as a learning resource for viscosity, namely the basic concepts and factors that affect viscosity in the form of the chocolate dough viscosity, fluid substances, the temperature in chocolate processing, and additives in the chocolate dough. (3) Learning resources based on local wisdom using COKSACAR can grow the entrepreneurial spirit, including (a) Motivation through the promotion of COKSACAR products. (b) Able to cultivate self-confidence, result-oriented, risk-taking, leadership, futureoriented, and able to find original and creative and innovative ideas. Learning resources that utilize the local potential of COKSACAR can foster a spirit of learning and train students entrepreneurial spirit
\end{abstract}

\section{INTRODUCTION}

Entrepreneurship is influenced by perceptions of the conditions of the business environment in the form of natural resources, work motivation, and quality of coaching (Khoiri, Kahar, \& Indrawati, 2018). Research that seeks to reveal the concept of science and economics (edupreneur science) through entrepreneurial activities in the creative business of Chocolate Sari Carica, hereinafter referred to as COKSACAR.

COKSACAR is a chocolate that is combined with Carica juice, giving rise to a different taste, generally chocolate or Carica fruit which is monotonous made candied only. The local potential is the potential of the area itself (Fitria \& Wisudawati, 2018). Wonosobo Regency is the producer and 
processing of Carica fruit, so it is not surprising that many industries have developed to process Carica fruit into various kinds of products that have high economic value such as Carica in syrup and sweets which are used as souvenirs typical of Wonosobo as part of local potential (Suprito, 2017). Currently, the development of the Carica processing industry in the Wonosobo Regency is supported by the increasing potential of Carica plants (Hasanah, 2010).

Based on data from the Agriculture Service of Wonosobo Regency in 2011 the number of Carica in the Dieng Plateau increased to reach 30,000 trees with a planted area of 115.77 ha. From these results, processed Carica fruit is only processed into Carica in syrup, which is increasingly causing saturation and less demand. Problems can be solved with a program that will be developed to eliminate boredom by creating Carica Fruit snack products with a variety of flavors through entrepreneurial activities.

Entrepreneurial activities through the stages of preparation, production, and marketing processes need to be studied systematically and require entrepreneurial skills. Based on the background of the problem, the purpose of entrepreneurial activities is to train creativity and skills in creating innovations, namely the manufacture of COKSACAR by serving Carica fruit that is different from others with additional variations in taste, to eliminate the saturation of fruit snacks which usually only have 1 taste, Increase the value selling Carica fruit so that it becomes a breakthrough in the manufacture of varied foods, opens new business opportunities to earn profits which can later open up jobs and reduce unemployment.

COKSACAR is the main attraction in the culinary, economic, and educational fields. COKSACAR can be used as a source of student learning to introduce local wisdom in various fields of matter, one of which is in the field of Physics, namely Viscosity by integrating the values of local wisdom into learning (Pradana, Futuha, \& Wahdaningrum, 2015). Not only that, this local wisdom-based learning resource, allows students to grow the entrepreneurial spirit by conducting COKSACAR studies. Learning resources are also expected to foster the entrepreneurial spirit of students so that students are not too dependent on what their parents have and can learn to be independent. The aim of the research is (1) to know the exploration of learning resources based on local wisdom; (2) to find out that local wisdom can be used as a learning resource in Viscosity material; (3) how to grow the entrepreneurial spirit with learning resources based on local wisdom.

\section{RESEARCH METHOD}

The type of research to be conducted is qualitative research with the following characteristics: (1) Conducted under natural conditions; (2) Research is more descriptive, data is in the form of sentences or pictures and does not emphasize numbers; (3) More emphasis on the process compared to the product; (4) Data analysis is done inductively; (5) More emphasis on the meaning or often referred to as observed data (Sugiyono, 2013).

Data sources are divided into two, namely primary data including COKSACAR, Carica, books on local wisdom, and other materials relevant to the material. Secondary Data Sources include scientific publications in the form of books, journals, articles, internet sites, and research results related to local wisdom, entrepreneurs, learning resources, and viscosity.

Data collection techniques using the participatory observation that researchers follow the activities and all processes in the manufacture of COKSACAR products, the COKSACAR manufacturing process, and surveys to UNSIQ Physics Students with learning media that have been made. Documentation technique by collecting photos of activities to research data. Data analysis using inductive and deductive analysis. 


\section{RESULTS AND DISCUSSION}

\section{COKSACAR Viscocity}

Viscosity is a measure that expresses the viscosity of a fluid or fluid to flow under the influence of shear. The equation used to determine the viscosity:

$$
\eta=\left(0.0026 t-\frac{1.175}{t}\right)-\left(\rho_{\text {cair }} \rho_{\text {udara }}\right)
$$

Description: $\eta=$ absolute viscosity (poise) and $t=$ time (seconds)

Based on the results of the COKSACAR production process activities, there is a process of blending the Carica fruit so that there is Carica juice, at this time the viscosity coefficient and liquid residue can be calculated. The results of the calculation of viscosity are presented in Table 1.

Table 1. Viscosity Measurement Results in Sari Carica

\begin{tabular}{cccc}
\hline Quantity & Without Filter & $\begin{array}{c}\text { Media-Soft } \\
\text { Cloth }\end{array}$ & $\begin{array}{c}\text { Media Parasite } \\
\text { Cloth }\end{array}$ \\
\hline Residu (cc) & 0 & 1500 & 2500 \\
$\begin{array}{c}\text { Viscosity Coeficient } \\
\text { (Pas) }\end{array}$ & 0,0112 & 0,0054 & 0,0026 \\
\hline
\end{tabular}

Based on Table 1, the properties of liquids are that they have different viscosity coefficients. Viscosity ( $\eta$ ) relates to the frictional force between the parts or layers of a liquid that move with each other. Different fluids have different viscosities. The results showed that the viscosity $(\eta)$ of unfiltered Carica juice, soft cloth media, and parasitic cloth medium were 0.0112 Pas, 0.0054 Pas, and 0.0026 Pas, respectively. The viscosity of the unfiltered Carica juice is higher or can be said to be thicker because the viscosity of the fluid is represented by the viscosity coefficient.

Fruit puree has a significant effect on viscosity the pasteurization process during processing can prevent the deposition process, because the formation of gelled by pectin so that the viscosity increases which causes the stability to increase (Kumalasari, Ekafitri, \& Desnilasari, 2015). Viscosity can be identified from fruit juice, one of which is Carica as a form of sediment and viscous liquid. Physical characteristics in the form of viscosity of Carica fruit juice (Amalia, 2016).

Application of the concept of viscosity through local wisdom of Carica fruit trees that have been processed into Carica fruit juice. the introduction of local potential to students as well as being able to study the physical properties of the Carica fruit juice fluid. Viscosity learning by calculating the travel time of marbles in three conditions of Carica juice, namely: the result of Carica juice without a filter media, using a fine cloth filter, and a parasitic cloth filter.

Based on Table 1, the amount of viscosity is based on the travel time of the marbles falling to the surface of the measuring cup. then the time is recorded, so that it can produce the speed of the object when it falls through the Carica fruit juice fluid, and calculated based on equation (1). The implementation of physics learning on the concept of viscosity is at the SMA level of class XI that the level of viscosity (viscosity) of fluid is stated by the viscosity of the fluid. If a ball or marble is dropped into a fluid, it will experience force friction between the surface of the object and the fluid. The friction of this magnitude is proportional to the coefficient of fluid viscosity. Furthermore, the concept of viscosity can be studied in college in basic physics courses, environmental physics, and ethnoscience about viscosity analysis and its problems in life.

The study of viscosity can be used as a reference in mixing the mixture of Carica juice, chocolate that has been melted and has been mixed with the milk powder so that in the production process and profits obtained after-sales can be maximized. If the dough and the dosage are not right, it can hamper the COKSACAR production process. 


\section{Potential Results of Business Development}

Based on the results of research, a country will be prosperous if it has entrepreneurs at least $2 \%$ of the population. In Indonesia, it is estimated that only 400,000 people are registered as independent entrepreneurs or around $0.18 \%$. It was recorded that from August 2016 to February 2017, educated unemployment rose by $9.88 \%$, confirmed by BPS that Indonesia's open unemployment rate in February 2017 was $5.33 \%$ or 7, 01 million people out of a total of 131.55 million people in the workforce. This reality is an important factor in the potential development of a promising COKSACAR business that needs to be designed as much as possible.

The potential for business development states entrepreneurship as a seriousness to create something new, make something different, improve individual welfare and provide added value to the community in line with the objectives of PKM-K activities in COKSACAR production. Furthermore, the achievement of the target of business output is seen in Table 2 .

Table 2. COKSACAR's Business Output Target

\begin{tabular}{clcc}
\hline No & \multicolumn{1}{c}{ Target } & \multicolumn{2}{c}{ Target Achievement } \\
& & Implemented & Not implemented yet \\
\hline 1. & Market Survey & $100 \%$ & - \\
2. & Fulfillment of Tools and & $90 \%$ & $10 \%$ \\
& Materials & & \\
3. & Production place & $100 \%$ & - \\
4. & Production Execution & $100 \%$ & - \\
5. & Marketing & $67 \%$ & $33 \%$ \\
& - Media Social & $90 \%$ & $10 \%$ \\
& - Brochure & $80 \%$ & $20 \%$ \\
& - Expansion to other & $30 \%$ & $70 \%$ \\
& cities. & & - \\
\hline 6. & Report & $100 \%$ & $8 \%$ \\
\hline
\end{tabular}

Based on Table 2, the level of achievement that has not been carried out is $8 \%$, with funds obtained from various parties amounting to 2,500,000, - (two million five hundred thousand rupiah) so that tools that are not yet available such as chocolate melting equipment, buying molds in various forms are presented Fig. 1.
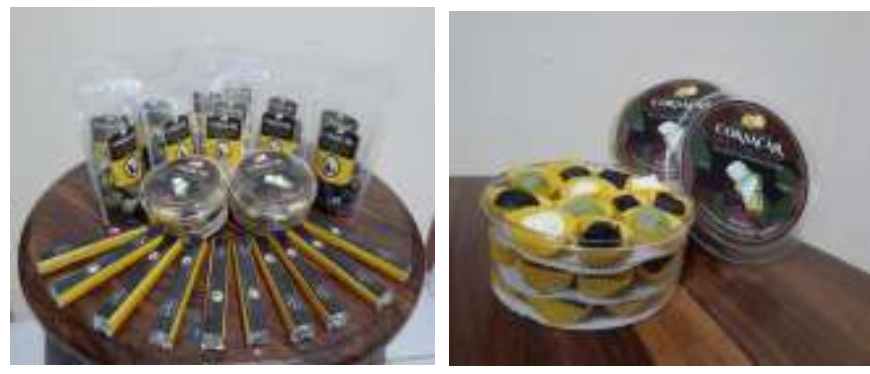

Fig 1. COKSACAR Product

COKSACAR production on a large scale and many variants can be done. In addition, the marketing that has not been implemented is for printing banners, large-scale brochures, and online markets so that they can be maximized again.

Business requires a good strategy to achieve long-term goals. Business strategies may include geographic expansion, diversification, acquisitions, product development, market penetration, business reductions, divestments, liquidations, and joint ventures. COKSACAR production is very promising to be developed sustainably because the raw materials scattered in the Dieng Wonosobo highlands are 
very unique and not all areas contain Carica fruit. Regarding local potential, the Ministry of Culture and Tourism of the Republic of Indonesia in 2011 stated that local excellence is a creative answer to geographical, political, historical, situational situations that are local and contain attitudes, views, and abilities of a community in managing the spiritual and physical environment in which it is located so that the production of COKSACAR with different chocolate flavor variants is a characteristic of the country above the clouds which of course does not exist in other areas. COKSACAR is a business that can maintain a competitive advantage of local potential because it is the only one in Wonosobo Regency, as evidenced by the results of Google or other online searches that there is no Sari Carica Chocolate yet, but a business is not enough to have a competitive advantage like this.

Achievement of business targets to achieve sustainable competitive advantage, namely: (1) continuously adapting to market trends because COKSACAR is still local, it needs extensive online marketing, preparation of human resources in the business that is updated scientifically, a sustainable network of partners to facilitate business, and (2) effectively formulate, implement and evaluate strategies that take advantage of COKSACAR's business factors (Harsi, 2011).

\section{COKSACAR Marketing Results}

The business of making Carica chocolate uses the 4P Marketing Mix analysis, namely regarding product policies, prices, promotions, and distributions: Product Policy in the form of chocolate containing 472 kilocalories of energy, 2 grams of protein, 62.7 grams of carbohydrates, 29.8 grams of fat, 63 milligrams of calcium, 287 milligrams of phosphorus, and 3 milligrams of iron, 30 IU of vitamin A, vitamin B1 0.03 milligrams and 0 milligrams of vitamin C. With a taste, aroma, and color that is almost the same as other chocolates, Carica chocolate has the advantage that it contains more Vitamin C. The price policy is based on profit and loss, so the price given to customers is Rp. 20,000,per pack based on the accountant's economic calculations, this price is lower than the price of competitors who usually offer prices between Rp. 25,000 to Rp. 40.000,00 per pack.

The sale of COKSACAR Typical of Negeri Atas Awan is enough to make people interested in trying new products using ingredients that are familiar to the people of Wonosobo. COKSACAR production has increased a lot, especially in the month of Ramadan. The following is a graph of COKSACAR's production in Fig. 2.

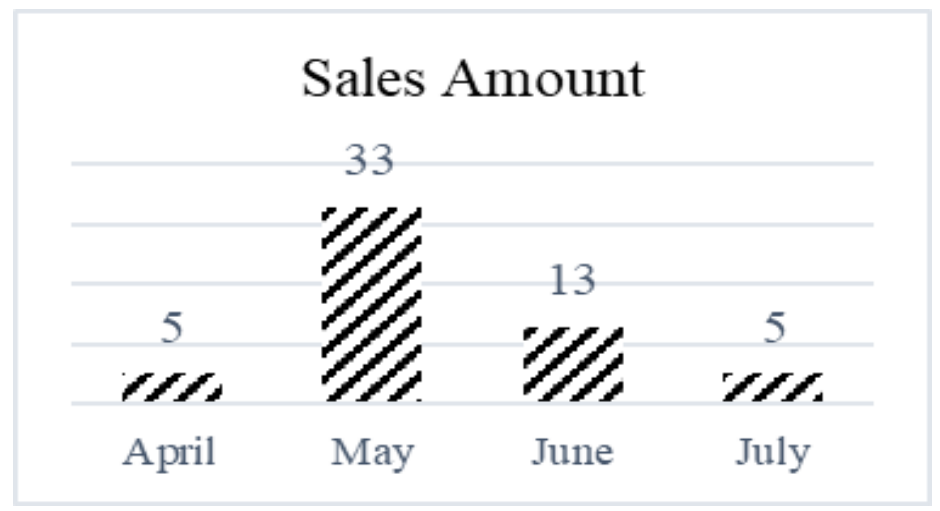

Fig 2. COKSAKAR Production Sales Results

The flavor variant favored by consumers is original. According to consumers, the original COKSACAR has more of a characteristic Carica fruit taste, "I prefer the original one because the taste of Carica can be felt more characteristically," said Mrs. Halimah, one of the buyers.

COKSACAR products are in great demand in the market based on Fig. 2 according to the tongue of all people today who are very fond of eating chocolate. COKSACAR products can compete with similar products because they are made with high quality and naturally healthy ingredients. Moreover, seeing the sales results in July which were very satisfactory, even in certain months the purchasing power of COKSACAR soared quite high. Through production activities, COKSACAR fosters entrepreneurial 
abilities and skills in carrying out production and marketing such as the industry in Carica SMEs in general (Mudrikah, 2013).

Forms of promotion include pamphlets, brochures, and other promotional media with online social media such as Whatsapp, Instagram, and Facebook. In addition, offers in stalls, shops, cooperatives, mini markets for sustainable cooperation. Distribution of production to consumers is carried out directly at the place of business or indirectly, namely by offering cooperation to various shops and minimarkets. Furthermore, the expansion of COKSACAR's marketing in collaboration with cooperatives (KUB Annisa), minimarkets (Sakinah), campus canteens, and food stalls. Business activities are strengthened by research (Nafingah, Laelatun, \& Irhandayaningsih, 2018) in program implementation and increasing MSMEs by way of collaboration with partners or communities, but there are still limitations to entrepreneurial activities, especially cross-regional marketing because the nature of promotion is still based on the needs of buyers.

Based on the analysis of the results of the entrepreneurial study, the COKSACAR business has the potential to be developed sustainably because the distinctive chocolate flavor of Carica is a new sensation and current trend and can reduce the saturation of the Carica fruit taste obtained from existing products such as sweets in syrup, chips, new business innovations. COKSACAR is used as a very promising business opportunity, even though some obstacles and problems are analyzed by SWOT as a step in developing sustainable business potential.

Learning resources that can be used by a teacher to achieve learning goals through learning resources based on local wisdom are sources used for learning on certain materials using local wisdom owned by an area (Khoiri and Haryanto, 2018). In Wonosobo there is local wisdom, one of which is Carica. Carica is an endemic fruit from Wonosobo and has many kinds of processing, one of the newest innovative products is COKSACAR.

COKSACAR's exploration is not only in the economic field but also in the world of education, which can be used as a learning resource (Wulansari and Admoko, 2021). One of the most difficult materials is viscosity. Viscosity is a material that describes the viscosity of a liquid or fluid. Viscosity can be influenced by several factors, including the presence of other substances, temperature, molecular weight and size, right, intermolecular strength, the molecular weight of solution concentration. The use of learning resources based on local wisdom is expected to foster the entrepreneurial spirit and learning resources.

The quality of physics learning in Indonesia can be said to below, it is suspected that there is a lack of attention to the socio-cultural environment as a source of learning (Khoiri et al. 2021). This requires an increase in the local culture of integrated learning based on local wisdom (Snively, Corsiglia, and Cobern 2001).

Local wisdom-based learning resources are sources of local wisdom owned by an area (Prasetyo, 2013). The use of learning resources based on local wisdom is expected to be able to improve national identity, cultural customs that have existed for a long time. This is in line with the results of Linda Dwiyanti's research with local wisdom-based learning implemented in the world of educational institutions, which can regenerate a sense of nationalism and strengthen the existence of Indonesian cultures amid the swift current towards the industrial era 4.0.

Based on the results of observations, COKSACAR was made to increase the local potential in Wonosobo with the formation of COKSACAR processed Carica fruit that is not monotonous and can become a snack among millennials today which exists in an era that has been heavily influenced by science and technology as a result of globalization. According to Aisa Nikmah Rahmatih et al in their research, globalization affects local wisdom through the human mindset, leading to cultural transformation which is divided into natural and unnatural transformations. In natural transformation, local culture is maintained but combined with foreign culture. COKSACAR tries to combine foreign 
cultures but still maintains local culture so that it can be accepted in various circles, of course, there is a great opportunity to enter the world of education which is used as a learning resource.

The process of making COKSACAR begins with the processing of Carica. Carica fruit used is Carica fruit with good quality and with a predetermined level of maturity. The process of making COKSACAR can be used as a learning resource in the subject of Viscosity. Materials that are often said to be difficult are usually rarely of interest to students. Viscosity is a measurement of the resistance of a fluid that is changed either by pressure or stress. Viscosity can also be said as a material that describes the viscosity of a fluid or fluid. The process of making COKSACAR has the concept of viscosity, namely during the process of making jam using Carica fruit juice. The entrepreneurial spirit is carried out by analyzing the characteristics of the entrepreneurial spirit, namely:

1. Confident

Confidence in someone with a steady feeling, not easily shaken even though there are many insults or words from other people who are less pleasing to the heart. Students have high confidence in developing products so that they can survive until now and continue to develop products following the times and still maintain the local characteristics of the product (Isrokatun et al., 2019).

2. Task and Result Oriented

Oriented to tasks and results towards goals and achievements that will be achieved by completing the PIMNAS implementation, students focus on the legality of products such as NIB, IUMK, and PIRT. The researchers were able to achieve legality after carrying out a series of activities from the Wonosobo District Health Office.

3. Risk-Taking

COKSACAR takes the risk by producing large-scale in all packaging. Students dare to take risks if the goods are not sold out, they will be returned and evaluated.

4. Leadership

Leadership must be owned by an entrepreneur in accepting suggestions and criticisms from employees and customers that are useful for the progress of COKSACAR's business.

5. Originality

Originality can have ideas that are different (Anwar et al., 2012; Sumarni and Kadarwati, 2020) from others and able to implement ideas on COKSACAR products as the first product in Carica processing. Previously, Carica was only processed into sweets and chips but dared to be different by processing Carica combined with chocolate so that it could compete and survive amid the times.

6. Future-Oriented

An entrepreneur must have a mature vision so that he can formulate strategies for the future(Khoiri \& Haryanto, 2018). COKSACAR has a vision of utilizing local wisdom to improve the economic level of Wonosobo.

7. Creativity and Innovation

Creativity in developing and finding opportunities (Amelia, Jumini, and Khoiri, 2021). COKSACAR has creativity in the form of developing Carica fruit processing, while its innovation is processing Carica fruit combined with chocolate which is favored by all circles.

The results obtained are learning resources based on local wisdom of COKSACAR processed food products. Viscosity learning resources in the COKSACAR manufacturing process by identifying the level of viscosity (viscosity) of the Carica juice used in making a clock and the factors that affect the level of viscosity of jam and chocolate dough when it will be printed.

The temperature factor used must be appropriate and the additives used must also match the recipe that has been made. If the level of viscosity, temperature, and additives used are not appropriate, then the resulting chocolate cannot be printed and the results will not be optimal. To foster the entrepreneurial spirit COKSACAR provides motivation (Jumini \& Sutikno, 2019) and approaches through product promotion and sales as well as concept explanations when conducting Viscosity practicums. 


\section{CONCLUSION AND SUGGESTION}

Based on the results of the study, it can be concluded that: (1) The form of exploration of learning resources based on local wisdom in the Wonosobo area with COKSACAR processed products with Carica fruit combined with chocolate. (2) The process of making COKSACAR as a learning resource for viscosity, namely the basic concepts and factors that affect viscosity in the form of the chocolate dough viscosity, fluid substances, the temperature in chocolate processing, and additives in the chocolate dough. (3) Learning resources based on local wisdom using COKSACAR can grow the entrepreneurial spirit, including Motivation through the promotion of COKSACAR products. Able to cultivate self-confidence, result-oriented, risk-taking, leadership, future-oriented, and able to find original and creative and innovative ideas.

\section{ACKNOWLEDGMENT}

We would like to express our gratitude to the Director-General Belmawa Dikti's Student Creativity Program (PKM) in 2019 for the Fund Assistance that has been given to us the PKM-K team from the Al Quran Science University, Central Java in Wonosobo as well as to the supervisor team and the academic community who always support the success of PKM us so that we have the opportunity and pass the 32nd PIMNAS at Udayana University Bali.

\section{REFERENCES}

Amalia, Lutviana. (2016). Pengaruh Penambahan Sari Buah Pepaya (Carica Papaya L.) terhadap Karakteristik Fisik, Kimia, Mikrobiologi dan Sensoris Minuman Fermentasi Berbasis Limbah Whey Keju. Universitas Sebelas Maret.

Amelia, T., Jumini, S., \& Khoiri, A. (2021). Analysis of Creativity and Attitudes Caring The Environment of Junior High School Students: Study of Environmental Physics Learning Using Learning Modules. Jurnal Pendidikan Fisika Indonesia, 17(June), 40-48.

Anwar, Muhammad Nadeem., Aness, Muhammad., Khizar, Asma ., Naseer, Muhammad., \& Muhammad, Gulam. (2012). Relationship of Creative Thinking with the Academic Achievements of Secondary School Students. International Interdisciplinary Journal of Education, 1(3), 1-4.

Fitria, Mariana \& Wisudawati, Asih Widi. (2018). The Development of Ethnoscience-Based Chemical Enrichment Book as a Science Literacy. International Journal of Chemistry Education Research, 2(1), 50-59.

Harsi, Rini. (2011). Strategi Pengembangan Industri Kecil. Universitas Sebelas Maret.

Hasanah, Uswatun. (2010). Proses Produksi Manisan Carica. Universitas Sebelas Maret.

Isrokatun, I., Syahid, A.A., Putri, H.E., Julia, J., and Sunaengsih, C. (2019). Problem Posing Skill of Elementary School Students. Journal of Physics: Conference Series, 1318(1).

Jumini, S., \& Sutikno, S. (2019). Physics Learning Integrated Science, Technology, Entrepreneurship. International Journal of Advanced Multidisciplinary Scientific Research (IJAMSR), 2(12), 116.

Khoiri, A. \& Haryanto, S. (2018). The 21St Century Science Skills Profile Based Local Wisdom Education (Tourist Attractions and Typical Foods in Regency of Wonosobo). Jurnal Penelitian Dan Pengabdian Kepada Masyarakat UNSIQ, 5(3), 361-71.

Khoiri, A., Kahar., \& Indrawati, R.T. (2018). Ethnoscience Approach in Cooperative Academic Education Programs (COOP). Journal of Physics: Conference Series, 1114(1).

Khoiri, A., Sunarno, W., Sajidan, S., and Sukarmin, S. (2021). Analysing Students' Environmental Awareness Profile Using Strategic Environmental Assessment [Version 1; Peer Review: 1 Approved]. F1000Research, 10(May), 1-16.

Kumalasari., Ekafitri., \& Desnilasari. (2015). Pengaruh Bahan Penstabil dan Perbandingan Bubur Buah terhadap Mutu Sari Buah Campuran Pepaya-Nanas (Effect of Stabilizer Type and Ratio of Fruit Puree on the Quality of Papaya-Pineapple Mixed Juice). 25(3), 266-76.

Mudrikah, Alfiah. (2013). Economic Education Analysis Journal. 2(1), 18-23. 


\section{VARIABEL 2 Variabel Vol. 4 No. 2 (October 2021). Page: 67-75}

Nafingah., Laelatun., \& Irhandayaningsih, Ana. (2017). Implementasi Program Perpuseru dan Peranannya dalam Kejajar Kabupaten Wonosobo. Fakultas Ilmu Budaya, Universitas Diponegoro.

Pradana, A., Futuha, H., \& Wahdaningrum. (2015). The Analysis of Environmental Degradation and Carica Agroforestry System as an Attempt of Environmental Restoration in Dieng Plateau. International Journal of Environmental Science and Development, 6(11), 861-67.

Prasetyo, Zuhdan Kun. (2013). Pembelajaran Sains Berbasis Kearifan Lokal. Prosiding: Seminar Nasional Fisika dan Pendidikan Fisika, 2(1), 246-56.

Snively, Gloria., Corsiglia, John., and Cobern, William W. (2001). Discovering Indigenous Science: Implications for Science Education. Science Education, 85(1), 6-34.

Sugiyono, S. (2013). Metode Peneltian Kualitatif dan R \& D. Bandung: Alfabeta.

Sumarni, W., and Kadarwati, S. (2020). Ethno-Stem Project-Based Learning: Its Impact to Critical and Creative Thinking Skills. Jurnal Pendidikan IPA Indonesia, 9(1), 11-21.

Suprito, Edy. (2017). UKM Carica Dieng Perluas Pangsa Pasar Ke Eropa. Seminar Nasional 6th UNS SME's SUMMIT, 282-290.

Wulansari, Nur Iva \& Admoko, Setyo. (2021). Identification of Physics Concepts in Reog Ponorogo's Dhadak Merak Dance as A Source of Learning Physics: An Analytical Study.” Berkala Ilmiah Pendidikan Fisika, 9(1), 105. 